\title{
EFFICIENT SOLAR COLLECTOR MATERIAL AND WORKING
}

\section{SANDEEP KUMAR \& SATBIR SINGH SEHGAL}

\author{
Department of Mechanical Engineering, Chandigarh University, Mohali, India
}

ABSTRACT
This paper concentrates on different solar water heaters and control systems. Research is discussed on
contributions and developments in solar energy collectors made up materials, heat transfer characteristics and
manufacturing challenges. Comparative analysis in term of $4 \%$ increase in performance of microchannel flat plate
collector is discussed. Paper also focuses on recent technology developed using micro channels in flat plate collectors with
actual temperature increase results. Suggestions have been raised for choosing the microchannel solar collector technology
instead of evacuated tube collectors and flat plate tube type collectors.
KEYWORDS: Materials, Heat Transfer, Flat Plate Collector, Evacuated Tubes Solar Collector, Heat Pipe Tube Collector \&
Microchannel Flat Plate Solar Collectors

Received: Jun 15, 2017; Accepted: Jun 30, 2017; Published: Jul 04, 2017; Paper Id.: IJMPERDAUG20174

\section{INTRODUCTION}

Solar water heaters utilize energy for the purpose of heating water from the sun in the form of radiations during a sunny day for domestic and industrial purposes these days. The radiations are catched up with help of a heat absorbent coated and layered water pipes in which, water as fluid flows. (I, II, III). The material of the tube pipes is normally takes as copper, because of its large thermal properties. The water heated with this mean is used for cooking purposes in domestics and also used in textile industry, fabric dying etc.

In India, there is still $8 \%$ population that uses a total of solar energy that comes from nature. If we look at the statics of the world health organization that around the globe, there are 12 million of deaths happening each year, due to the fumes inhaled by the persons that comes from the burning of the wood and coal. (IV, V, VI). These fumes give rise to various breathing diseases also, so with mean of time; there is developed kind of water heating machines that works on principal of natural thermosyphone, whereas in India, we receive $5 \times 1015 \mathrm{kWh} /$ year of solar energy (VII - XIII). We use this free energy for our use, by the mean of flat plate collectors, evacuated tube collectors, micro channel flat plate collectors (XVI, XV).

These solar energy collectors are possessed with a radiation collection mechanism that gives us enormous collector performance year ahead, along various weather conditions (XVI, XVII).There are many ways to talk about the performance of the collectors or to increase the working performance by increasing the surface area of contact of radiation, or by maintaining the angle of the collector (XVIII, XIX).

\section{Solar Energy Collector Fabrication Material}

A solar flat plate collector is mainly an assembly of transparent glass cover of $4 \mathrm{~mm}$ approximate thickness with four copper pipes of mainly each of $15 \mathrm{~mm}$ thick pipes, properly welded together with inlet hose pipe and outlet hose pipe. (XX, XXI). The choosing of material is the main aspect, which is usually taken of high heat carrying 
capacity with large other thermal properties, so copper be the best as shown in the "figure 1".

The "figure 2" shows the graph between the collector efficiency to the difference between collector and ambient temperature in ${ }^{\circ} \mathrm{c}$. Main parts of graph system are the optical loss and the thermal losses. (XXII, XXIII).

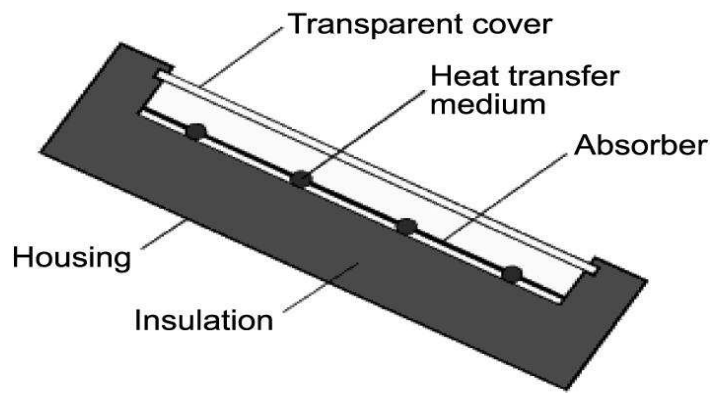

Figure 1: Flat Plate Collector (https://energy.gov/eere/solarpoweringamerica)

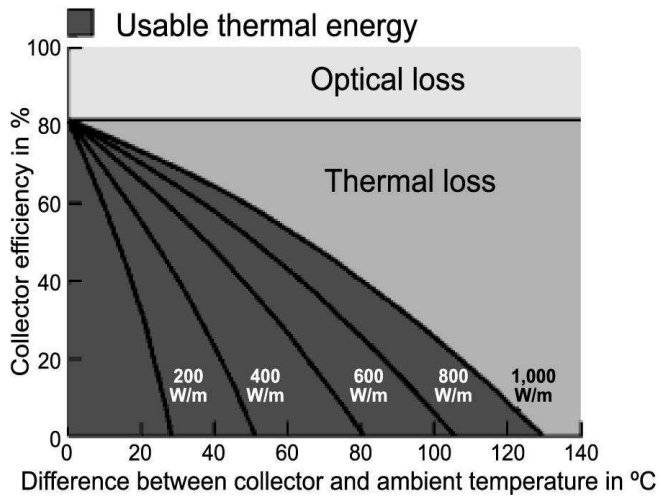

Figure 2: Efficiency graph of solar collector performance (www.solarserver.de/wissen/sonnenkollektoren-e.html\#hoc)

Table 1: Types of Collector with its Conversion Factor and Thermal Loss Factor Around a Specific Temperature Difference (XXIV, XXV)

\begin{tabular}{|l|c|c|c|}
\hline \multicolumn{1}{|c|}{ Type of collector } & Conversion Factor & Thermal loss Factor $\left(\mathbf{k W} / \mathbf{m}^{\mathbf{2}}\right)$ & Temperature \\
\hline Flat plate collector & $0.66-0.83$ & $2.9-5.3$ & $20-80$ \\
\hline Evacuated-plate collector & $0.81-0.83$ & $2.6-4.3$ & $20-120$ \\
\hline Reservoir collector & about 0.55 & about 2.4 & $20-70$ \\
\hline Evacuated-tube collector & $0.62-0.84$ & $0.7-2.0$ & $50-120$ \\
\hline
\end{tabular}

The "Table 1" above shows there are four types of collectors, taken mainly showing their conversion factor ranging from 0.55 to 2.9 and having thermal loss factor considered in $\mathrm{kW} / \mathrm{m}^{2}$ from 0.7 to 2.9. (XXVI, XXVII). With rise in heat radiation, the temperature ranges are from $20^{\circ} \mathrm{C}$ to $120^{\circ} \mathrm{C}$ (XXVIII, XXIX).

\section{INSULATION}

Each collector that is meant for solar radiation absorption is always meant to heat losses either from the frame itself, or from the rough weather conditions, so insulation is very much important to prevent heat losses from back side of apparatus and from side walls of solar water heater. Insulation must be such like that, it be resistant to resist $150^{\circ} \mathrm{C}$ of temperature in collectors. Main type of insulator is of black paint with absorber properties and to hold $200^{\circ} \mathrm{C}$ of temperature. (XXIX) 
The insulators used in today's absorbers are having properties which doesn't shrink, melt at high temperature radiation $(\mathrm{XXX})$. These have specific properties also that, they didn't give off vapors which could condense on the collector cover and results in reduce its solar transmittance.

In today's times we use paint layered thin film temperature resistant insulation, which is always in contact with absorber. We use these because these are less expensive in cost (XXXI).

This procedure is always put in use, because of the water penetration risk in solar collector, so the thermal conductivity, durability properties are also considered (XXXII). In almost all the solar collectors, there is glass fibre used, which is easily available and cheap to purchase, whatever is the case of a small production or the big scale (XXXIII). Glass fibre insulation is cheap, but there are limitations in it, because it gets deteriorated whenever it comes in contact with water or moisture (XXXIV), so, it should be ventilated and supported enough, so that, there must be no blockage in it. In today's times, there is also a material called mineral wool, popular enough for attaining the higher temperatures having a little expensive which increases the collector box.

\section{FRAME}

In the body of a collector, there is a rigid structure, which has to hold whole of the structure of pipes and other things attached with it, such as glass wool. The cover glass weight, which is of $4 \mathrm{~mm}$ in width's weight, has to be carried over by the frame also.

The frame provides toughness to structure of the collector, and is designed with light material aluminium extruded profiles. The frame is anodized painted for the corrosion protection from the sides. Another material as galvanized steel sheet is used having thickness of order 0.5-1.0 mm. (XXXV). The frame and the glass cover are mainly important for the effective flow, such like in case of microchannel solar water collector for collector's better reliability.

Frame is also used for the protection from losses, caused due to wind, so absorber is provided and glazing is done in. These are made up of various materials like aluminium sheet extrusion, welded and formed.

The frame is such a way made to withstand weather conditions, proof from fire, durable, strong and permanently sealed against moisture effects. In the frame, the number of joints and seams must be minimized enough to make it sealed from foreign particles like salt air, pollution from industry, smog in atmosphere (XXXVI).

\section{COLLECTOR SEALANTS}

All the solar collectors depend strongly upon the sealing assembly around the cover body and the water fluid inlet and outlet pipe connections.

Sealants must have the property to withstand high temperatures and rough weather conditions. They must possess flexibility to water tightness and thermal movement of the collector components, whenever the frame is dismantled for maintenance through their lifetime. Sealants must withstand attack by birds also. Ethylene propylene or Diene monomer are used as sealants in all solar collectors.

These have high withstanding to high temperatures, salty rains, acid rains etc. The costing is very high of this sealant and is durable. 


\section{THERMAL COLLECTOR'S BODY COATING MATERIALS}

This is the method, where we do paint the selective plastic material on sides of steel boxes, inner side and outside, if necessary such like in the hot water storage tanks. The plastic coatings must be prevented from contact with any kind of food contact. These coatings are done for the corrosion protection. This becomes useful to seal edges of joints done by welding or by riveting. The process of coating involves raising the temperature of box or tank extruded of welded frame to $260^{\circ} \mathrm{C}$, and plastic material is applied on all side corners as well body of thickness ranging from $0.320 \mathrm{~mm}$.

Table 2: Material Thermal Conductivity (XXXVII)

\begin{tabular}{|l|c|c|}
\hline \multicolumn{1}{|c|}{ Material } & $\begin{array}{c}\text { Thermal Conductivity } \\
\text { (W/m8C) at } \mathbf{2 5 8}^{\circ} \mathbf{C}\end{array}$ & $\begin{array}{c}\text { Specific Heat Capacity } \\
-\mathbf{C p}(\mathbf{k J / k g ~ K})\end{array}$ \\
\hline Silver & 429 & 0.23 \\
\hline Copper & 401 & 0.39 \\
\hline Gold & 310 & 0.13 \\
\hline Aluminium & 250 & 0.91 \\
\hline Brass & 109 & n/a \\
\hline Iron & 80 & 0.46 \\
\hline Steel & 46 & 0.5 \\
\hline
\end{tabular}

\section{SOLAR THERMAL EVACUATED TUBULAR COLLECTORS}

The evacuated tube collectors in "figure 3" consists of a large $150 \mathrm{~mm}$ diameter glass tubes made up of borosilicate material with small tubes of $65 \mathrm{~mm}$ appox, based on iron soda lime glass (XXXVII). The phenomenon behind the working of tubes is that, the heat transfer fluid flows directly through the metallic absorber with, also the absorber tube is realized as a heat pipe system.

Table 3: Evacuated Tubes Manufacturing Specification (XXXVIII)

\begin{tabular}{|c|l|l|}
\hline S. No. & Tube Part & \multicolumn{1}{c|}{ Specification } \\
\hline 1 & Absorber & Copper tubes ultrasonically welded on copper sheet metal \\
\hline 2 & Coating & Spectrally selective absorber coating, black chrome directly on copper sheet metal \\
\hline 3 & Tube & Borosilicate glass \\
\hline 4 & Tube distance & $112 \mathrm{~mm}$ from centre to centre in a tube case \\
\hline
\end{tabular}

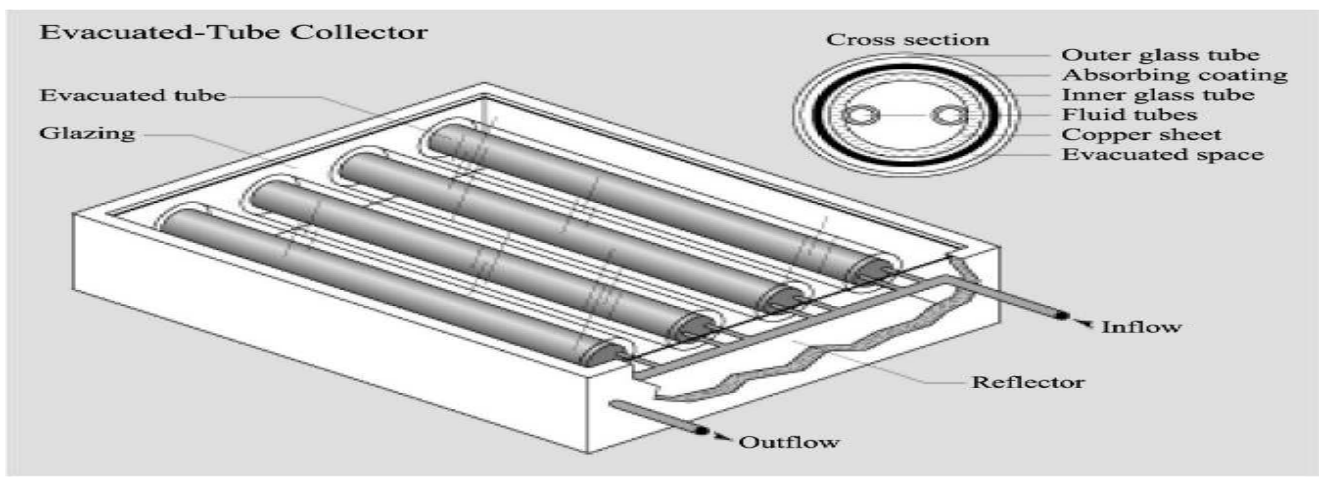

Figure 3: Evacuated-Tube Collector (XXXII)

Performance of the tube type collector is quite high, because the radiation can be absorbed from all sides of the tubes as in comparison with the flat plate collector. That's why, where a large amount of sunny weather conditions are possible, there an extreme temperature of $250^{\circ} \mathrm{C}$ can be achieved. But, its handling costs are very high because of fragility in the nature of all glass made. 


\section{Silent Features of Tubes}

- The part namimgcombine glass vacuum tube and copper heat pipe as one unit making it simple in design.

- The use of super-conducting working liquid in copper heat pipe makes it highly efficient in gaining high thermal properties.

- The evacuated tubes have very high degree of vacuum.

- In evacuated tubes, without water flow in glass vacuum tube, so it can bear an $-2308^{\circ} \mathrm{C}$ of cold temperature conditions.

- The evacuated tubes find application in high pressure solar water heater and solar projects.

Energy Gain Graph Year Wise (Flat Plate Vs Tubular Collectors)

In the Figure - 4, there is a wide range of yearly heat gained vs. number of years from 1970 to 2010 has been shown, as a part that the efficiency of the tube type evacuated collectors and flat plate collectors with small difference of temperature performance gained in years.

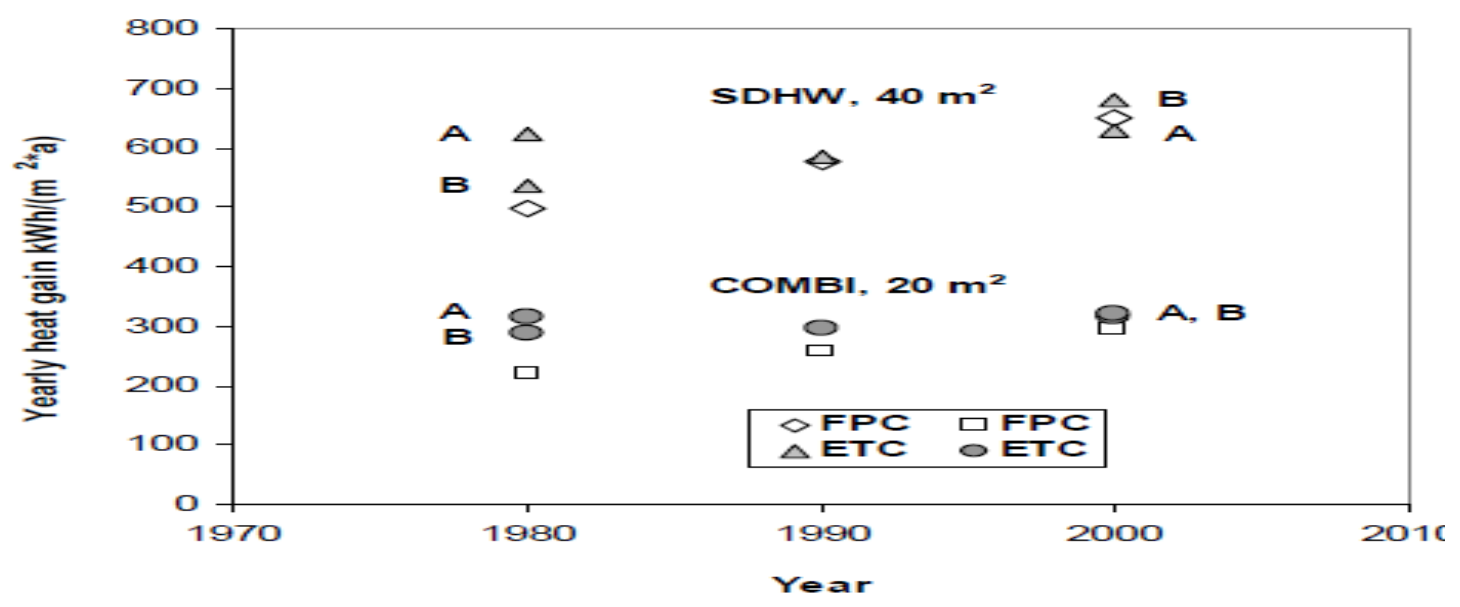

Figure 4: Comparison of Flat Plate and Tubular Collectors (J. (2004) XXXI)

MICROCHANNEL TYPE FLAT PLATE SOLAR COLLECTOR

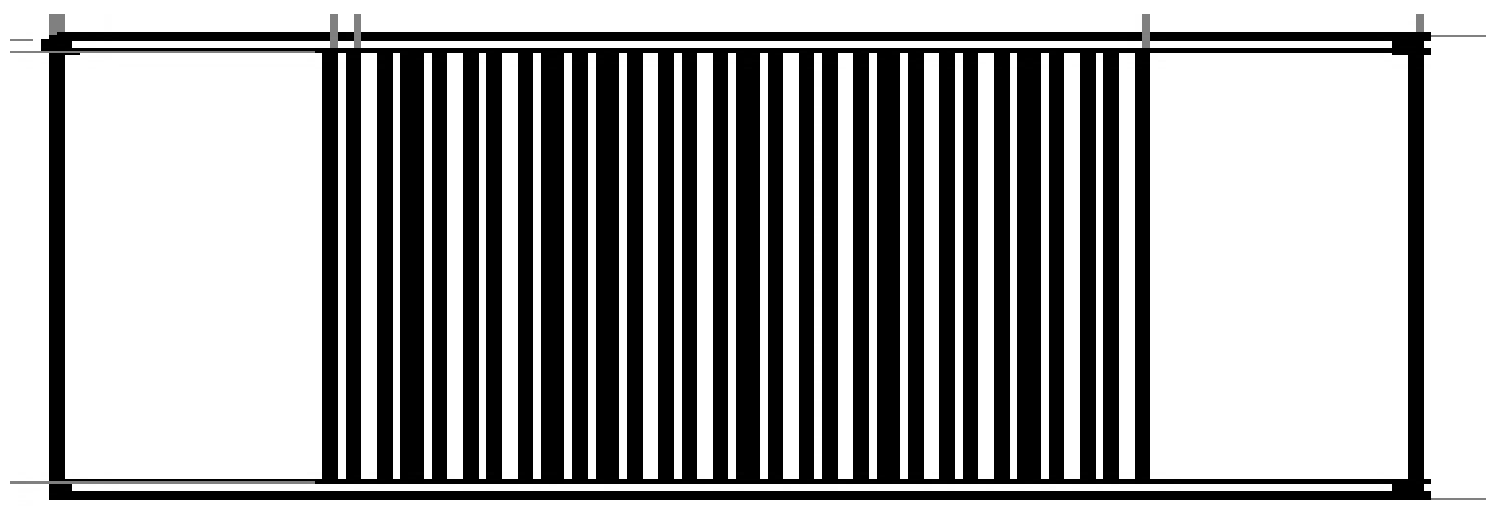

Figure 5: Simulated Microchannel Flat Plate Solar Collector (For Simulation with Water in Solid Works Software) 


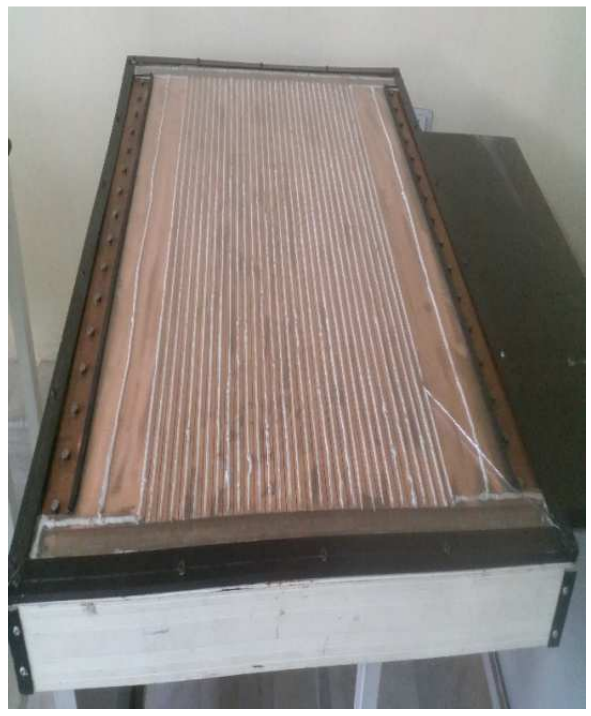

Figure 6A: Original Machined Microchannelsolar Flat Plat Collector with Various Channels Milled on Vertical Milling Machine

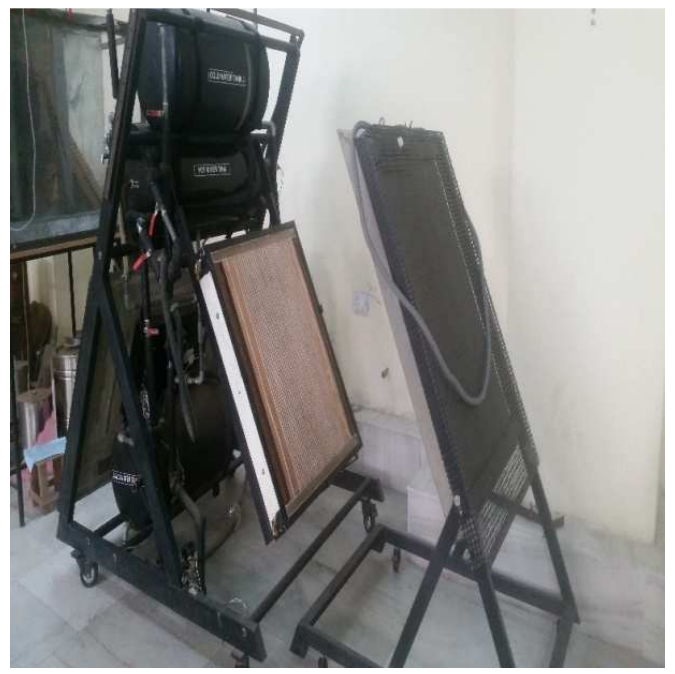

Figure 6 B: Solar Testing Panel from Ecoscence for Microchannel Testing

These types of collectors are introduced these days on the idea of increasing the surface area, so that, the contact surface of plate may absorb maximum solar radiation. For selection of material to manufacture these type of special collectors, normally of high thermal efficient materials be selected, like copper. A microchannel is a $1 \mathrm{~mm}$ wide and $600 \mathrm{~mm}$ length slot. The material taken may be copper or aluminium, depending upon the requirement also. Efficiency of such like solar collector is found to be $40 \%$ as $10 \%$ higher than the tube type solar collector or evacuated tube type collectors.

Table 4: Material Density (M. (1986) XXXI)

\begin{tabular}{|l|c|}
\hline Material & $\begin{array}{c}\text { Thermal Conductivity } \\
\text { (W/m K) }\end{array}$ \\
\hline Copper & 385.0 \\
\hline Gold & 314 \\
\hline Brass & 109.0 \\
\hline Aluminum & 205.0 \\
\hline
\end{tabular}


Table 5: Material Thermal Conductivity (XXXII)

\begin{tabular}{|c|c|c|}
\hline Metal & Density $\mathrm{g} / \mathrm{cm}^{3}$ & Density lb/in ${ }^{3}$ \\
\hline Iron & 7.8700 & 0.284000 \\
\hline copper & 8.9600 & 0.324000 \\
\hline Silver & 10.4900 & 0.37900 \\
\hline Lead & 11.3600 & 0.41000 \\
\hline
\end{tabular}

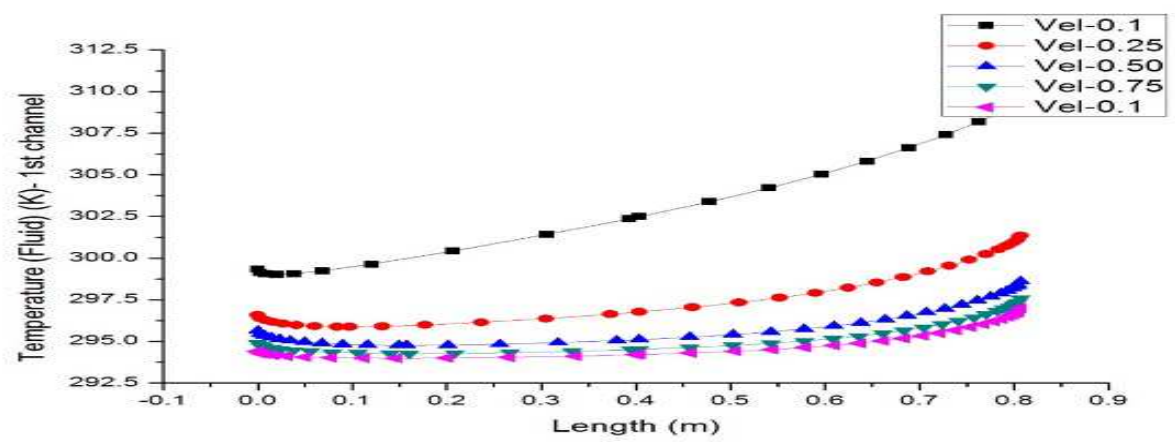

Figure 7: Temperature Performance Comparison Graph at $1^{\text {st }}$ Channel with Various Velocities on Microchannel Flat Plate Solar Collector

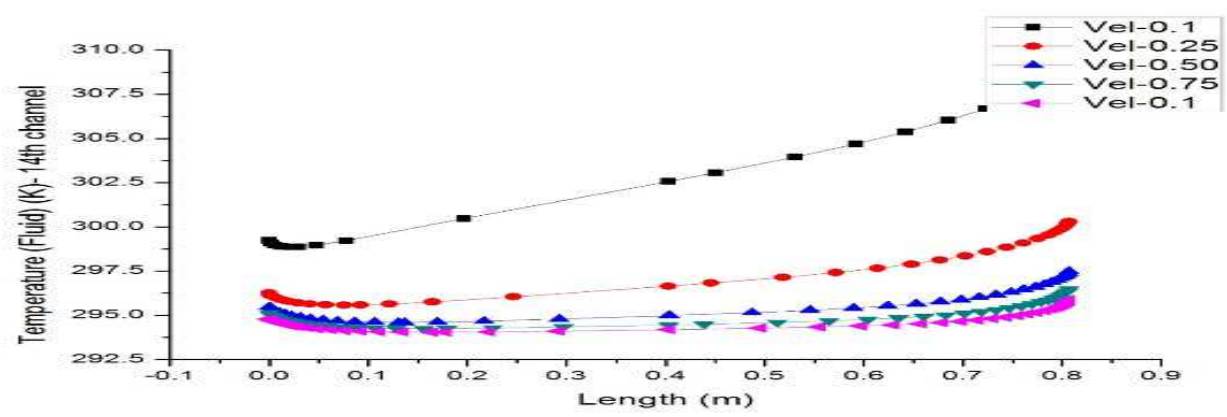

Figure 8: Temperature Comparison Graph at $14^{\text {th }}$ Channel with Various Velocities on Microchannel Flat Plate Solar Collector

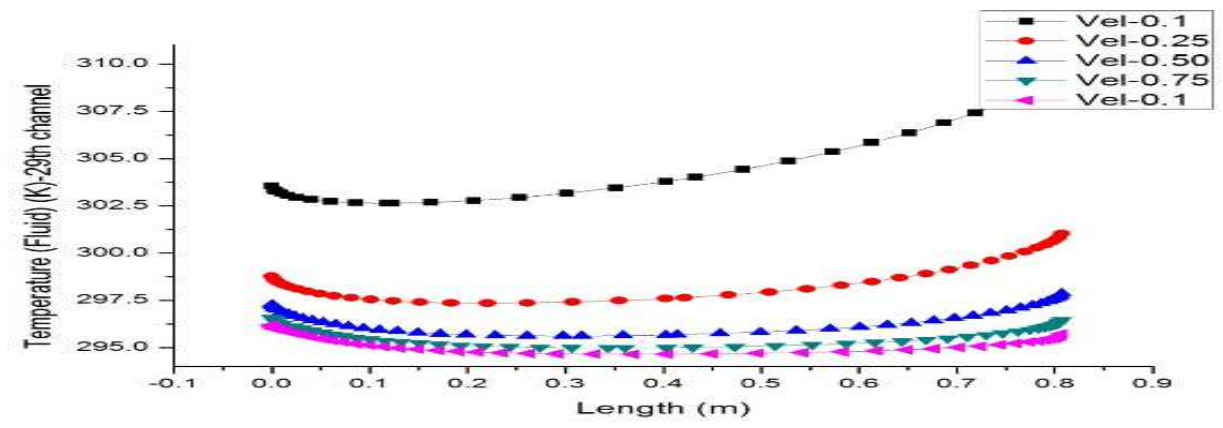

Figure 9: Temperature Comparison Graph at $29^{\text {th }}$ Channel with Various Velocities on Microchannel Flat Plate Solar Collector

The selection of material depends upon the density of material such like shown in the above table of metals, with their thermal conductivity, which is found to be of copper, as the highest.

The use of microchannel flat plate collector results in 
- $\quad$ Reduced cost of materials and manufacture.

- Resistance to corrosion build-up, where maintenance costs will be lower.

- $\quad$ Reduced weight and easy installation.

- Simulated results show a $4 \%$ increase in efficiency at 0.1 velocities.

\section{CONCLUSIONS}

- The material copper selected to manufacture microchannel collectors.

- Glass as transparent cover which is relatively inexpensive.

- Vacuum insulation a no cost material.

- Selective coating material which is relatively cheap, as compared to high output of energy of solar collector.

- $\quad$ Super conducting working fluid water (very low cost).

- Micro channel flat plate solar collector with principal based upon to increase the surface area for heat radiations collection has gained more heat and working efficiency as shown in graphs

- High temperature rate of $4 \%$ is attained during experimentation on solar testing machine using micro channel flat plate collector in comparison with conventional tube type collector and evacuated tube collector experimentally.

\section{REFERENCES}

1. Vasiliev, L.L. (2005), Heat pipes in modern heat exchangers, Applied Thermal Engineering, Vol. 25 No. 1, pp. 1-19.

2. Zhiqiang, Y. (2004), Development of solar thermal systems in China, Vol. 86 No. 3, pp. 427-42.

3. X. (2004), A novel hybrid heat pipe solar collector/CHP system. Part 1: system design and construction, Renewable Energy, Vol. 29 No. 15, pp. 2217-33.

4. Wu, C., Mantell, S.C. and Davidson, J. (2004), Polymers for solar domestic hot water: long-term performance of PB and nylon 6, 6 tubing in hot water, Solar Energy Engineering, Vol. 126 No. 1, pp. 581-6.

5. Kehrer, M., Kunzel, H. and Sedlbauer, K. (2003), Ecological insulation materials: does sorption moisture affect their insulation performance, Journal of Thermal Envelope and Building Science, Vol. 26 No. 3, pp. 207-12. (Elsevier)

6. Mathioulakis, E. and Belessiotis, V. (2002), A new heat-pipe type solar domestic hot water system, Solar Energy, Vol. 72 No. 1, pp. 13-20.

7. Tsilingiris, P.T. (2002), Back absorbing parallel plate polymer absorbers in solar collector design, Energy Conversion and Management, Vol. 43 No. 1, pp. 135-50.

8. Lee, B. (2001), The progress and prospect of middle/high temperature evacuated tubular solar collector, Renewable Energy, Vol. 24 Nos 3-4, pp. 539-44.

9. Zhang, Q-C. (2000), Recent progress in high-temperature solar selective coatings, Solar Energy Materials and Solar Cells, Vol. 62 No's 1-2, pp. 63-74.

10. Joudi, K.A. (1999), Computer simulation of a two phase thermosyphon solar domestic hot water heating system.

11. Energy Conversion and Management, Vol. 40, pp. 775-93. Kalogivou, A.S. and Dentsoras, A.P. (1999), Modelling of solar 
domestic water heating systems, Solar Energy, Vol. 65, pp. 333-4.

12. Koltun, M., Gukhman, G. and Gavrilina, A. (1994), Stable selective coating 'black nickel' for solar collector surfaces,

13. Wilson, H.R. (1992), Transmission switching using micro-encapsulated liquid crystal films, Solar Energy, Vol. 49 No. 5 , pp. 435-45.

14. Hamdan, M. and Elwerr, F. (1996), Thermal energy storage using a phase change material, Solar Energy, Vol. 56 No. 2 , pp. 183-9.

15. Nahar, N.M. and Gupta, J.P. (1987), Performance and testing of improved natural circulation type solar water heater in arid areas, Energy Conversion and Management, Vol. 27, pp. 29-32.

16. Norton, B., Probert, S.D. and Gidney, J.T. (1987), Diurnal performance of thermosyphonic solar water heaters - An Empirical Zhao.

17. Vaxman, M. and Sokolov, M. (1986), Effects of connecting tubes in thermosyphonic solar systems, Solar Energy, Vol. 37, pp. 323-31.

18. Morrison, G.L. and Tran, N.H. (1984), Simulation of the long term performance of thermosyphon solar water heaters, Solar Energy, Vol. 33, pp. 515-26.

19. Lane, G.A. (1983), Solar Heat Storage: Latent Heat Materials Volume I: Background and Scientific Principles, Vol. 1, CRC Press, Inc., Boca Raton, FL.

20. Design Guidelines, D. Reidel Publishing Company Co, Holland, 1985.

21. Kirk and Othmer (Eds) (1982), Encyclopedia of Chemical Technology, Wiley, New York, NY.

22. ASHRAE, SPSP10/1980, Handbook of Experiences in the Design and Installations of Solar Heating and Cooling Systems.

23. Waksman, D. and Dawson, A. (1980), The influence of environmental exposure on solar collectors and their materials, Proceedings of the AS/ISES Conference, 3.1, pp. 415-9.

24. Anderson, B.: Solar Energy, Fundamentals in Building Design, McGraw-Hill, 1977.

25. Winegarner, R.M. (1976), Heat-mirror - a practical alternative to the selective absorber, Proceedings of the Conference of the American Section of ISES and SES of Canada, Sharing the Sun, 6, pp. 337-48.

26. Simon, B.F. (1975), Solar collector performance evaluation with NASA-Lewis solar simulator - Results for an evacuated tubular selectively coated collector with a diffuse reflector, NASA TMX 71695.

27. Hsieh, C.K. and Coldeway, R.W. (1974), Study of thermal radiative properties of antireflection glass for flat plate solar collector cover, Solar Energy, Vol. 16, pp. 63-72.

28. Zulovich, J.M. (n.d.), Active solar collectors for farm buildings, available http://muextension.missouri.edu/ xplor/agguides/agengin/g01971.htm

29. Hollands, K.G.T. (1965), Honeycomb devices in flat plate solar collectors, Solar Energy, Vol. 9, pp. 159-64.

30. Yellot, J.I. and Sobotka, R. (1964), An investigation of a solar water heater performance, Trans. ASHRAE, Vol. 70, p. 425.

31. Whillier, A. (1963), Plastic cover for solar collectors, Solar Energy, Vol. 7, pp. 148-51.

32. Hottel, H.C. and Woertz, B.B. (1942), Performance of flat plate solar heat collectors, Trans ASME, Vol. 64, pp. 91-104.

33. Domestic solar water heater, J. Sci. Ind. Res., Vol. 18A, pp. 51-8. 
34. DIN 4753.1: Water heating installations for drinking water and service water; design, equipment and testing.

35. DIN 4753.4: Water heating installations for drinking water and service water. Corrosion protection on the water side by thermosetting resin-bonded lining materials; requirements and testing coating materials requirements and testing.

36. ISO 9806-2: Test methods for solar collectors - Part 2: Qualifications test procedures.

37. EN 12975-2: Thermal solar systems and components Collectors - Part 2, Test methods.

38. Solar Energy Materials and Solar Cells, Vol. 33 No. 1, pp. 41-46. 